\title{
Compliance to micronutrient supplementation in children 3 to 24 months of age from a semi-rural community in Mexico
}

\author{
Fernando López-Flores, MSc, ${ }^{(1)}$ Lynnette Marie Neufeld, PhD, ${ }^{(2,3)}$ Daniela Sotres-Álvarez, Dr PH, ${ }^{(4)}$ \\ Armando García-Guerra, MSc, ${ }^{(2)}$ Usha Ramakrishnan, PhD. ${ }^{(5)}$
}

\author{
López-Flores F, Neufeld LM, Sotres-Álvarez D, \\ García-Guerra A, Ramakrishnan U. \\ Compliance to micronutrient supplementation \\ in children 3 to 24 months of age from a \\ semi-rural community in Mexico. \\ Salud Publica Mex 20 12;54:470-478.
}

\begin{abstract}
Objective. To identify associated factors to compliance for multiple micronutrient (MM) or iron and vitamin A (IVITA) supplementation, in children ( 3 to 24 months old). Materials and methods. A database ( $\mathrm{n}=465$ children) from a randomized, controlled, clinical trial, carried out in a semi-rural setting in Mexico, was analyzed. The compliance rate of MM and IVITA supplements was calculated. Adequate compliance rate $(A C>80 \%)$, and its association with children and households characteristics, was determined. Results. The compliance mean was high (MM:78.2\%, IVITA:80. I\%; $p<0.05$ ). The odds of AC were $59 \%$ greater in the children of IVITA than with MM group, although the estimate was only marginally significant $(p=0.052)$. Maternal education $(p<0.00 \mathrm{I})$, child birth weight $(p=0.003)$, and children with cough $(p<0.00 \mathrm{I})$ or fever $(p=0.024)$ were significantly associated with $A C$ and significantly marginal was maternal indigenous $(p=0.07 I)$. Conclusion. The high AC was consistent with others efficacy studies. More research is needed to document physiological, cultural, social and operative factors affecting compliance with supplementation.
\end{abstract}

Key words: Medication adherence; dietary supplements; nutrients; child; Mexico

\author{
López-Flores F, Neufeld LM, Sotres-Álvarez D, \\ García-Guerra A, Ramakrishnan U. \\ Cumplimiento de la suplementación con micronutrimentos \\ en niños de 3 a 24 meses de edad en una \\ comunidad semirrural en México. \\ Salud Publica Mex 2012;54:470-478.
}

\section{Resumen}

Objetivo. Identificar factores asociados con el cumplimiento del consumo de suplementos con micronutrimentos múltiples (MM) o con hierro y vitamina A (FEVITA) en niños ( $<24$ meses de edad). Material y métodos. Información de un ensayo clínico aleatorizado, doble ciego en una localidad semirrural en México. Se calculó el porcentaje de cumplimiento $(n=465$ niños), cumplimiento adecuado (CA: $>80 \%$ ) y su asociación con varias características. Resultados. El cumplimiento fue alto (MM: 78.2\%, FEVITA: $80.1 \%$; $p<0.05$ ). Los momios de CA fueron $59 \%$ mayores en niños del grupo FEVITA que en $\operatorname{MM}(p=0.052)$. Escolaridad materna $(p<0.00 \mathrm{I})$, peso al nacer del niño $(p=0.003)$, porcentaje de tiempo con tos $(p<0.00 \mathrm{I})$ y con fiebre $(p=0.024)$ y marginalmente, la condición indígena materna $(p=0.07 \mathrm{I})$ se asociaron con el CA. Conclusiones. La alta tasa de cumplimiento fue consistente con otros estudios. Es necesaria mayor investigación sobre factores fisiológicos, culturales, sociales y operativos relacionados con el cumplimiento del consumo de suplementos.

Palabras clave: cumplimiento de la medicación; suplementos dietéticos; nutrientes; infantil; México

(I) Secretaría de Salud de Nayarit. Tepic, Nayarit, México.

(2) Instituto Nacional de Salud Pública. Cuernavaca, Morelos, México.

(3) Micronutrient Initiative. Ottawa, Canada.

(4) Department of Biostatistics, Gillings School of Global Public Health, University of North Carolina. Chapel Hill, NC, USA.

(5) Nutrition and Health Sciences Program and Hubert Department of Global Health, Rollins School of Public Health, Emory University. Atlanta, USA.

Received on: March II, 20II - Accepted on: April 17, 2012

Corresponding author: Dra. Lynnette Marie Neufeld, PhD. Micronutrient Initiative. 180 Elgin St. Suite 1000, Ottawa, Ontario, Canada. K2P 2K3.

E-mail: Ineufeld@micronutrient.org 
$\mathrm{M}$ icronutrient deficiency in children less than 2 years old is an important public health problem in Mexico. Anemia prevalence (hemoglobin concentration $<11.0 \mathrm{~g} / \mathrm{dL}$ ) is $40.5 \%$ in children 12 to 23 months age), ${ }^{1}$ 27.9\% of children have depleted vitamin Astores (serum retinol $<20 \mathrm{ug} / \mathrm{dL}$ ), 33.9\% have zinc deficiency (serum zinc $<65 \mathrm{ug} / \mathrm{dL}), 30.3 \%$ have deficiency of vitamin $\mathrm{C}$ (serum ascorbic acid $<0.2 \mathrm{mg} / \mathrm{dL}$ ), and $62.4 \%$ vitamin E (serum tocoferol $<600 \mathrm{ug} / \mathrm{dL}$ ). ${ }^{1,2}$

In order to reduce nutrition problems, diverse programs and food and nutrition policies have been implemented in Mexico, which include subsidies, fortified food distribution and micronutrient supplementation. ${ }^{3}$ Of these, supplements have been shown to have the highest efficacy to prevent and control micronutrient deficiencies during childhood. ${ }^{4-6}$ However, in a program context, an important factor to predict the intervention effectiveness is compliance to supplement consumption. 7,8

Most of the published studies related to compliance with supplementation have focused on type, dosage and frequency of supplements containing iron and its relation to side adverse effects such as constipation, nausea, vomiting and diarrhea. ${ }^{9-13}$ However, there is little evidence that side effects are the main cause for failure to comply. ${ }^{10}$ Some publications have associated compliance with supplement taste ${ }^{14}$ and type (syrup, powder and porridge), ${ }^{13,15}$ others with psychological factors (self-esteem and health beliefs) ${ }^{12}$ or logistic aspects (storage, supervision and geographical barriers). ${ }^{10}$

Few studies have been published that explore predictors of compliance with nutritional supplements. The few that exist are difficult to compare given differing compliance definitions and measurement methods. ${ }^{10-12}$ This limits our ability to understand barriers to compliance and formulate strategies to improve it. ${ }^{16}$ Therefore, it is suggested that when a study is designed to evaluate the level of compliance, social and demographic characteristics such as education, housing, family income and employment status to be included. ${ }^{17}$ Understanding factors related to compliance to micronutrient supplementation may help program implementers to invest resources in designing and implementing strategies to enhance it.

The objective of this study is to compare compliance with multiple micronutrients or iron and vitamin A supplementation in children 3 to 24 months of age, and to explore factors associated with compliance in a randomized, double-blind, clinical trial in Mexico. ${ }^{18}$ In order to accomplish this objective, we sought to answer the following research questions: 1) What is the rate of compliance in children from 3 to 24 months of age, supplemented with two different micronutrient supple- ments?, 2) Does compliance differ by supplementation group?, 3) Is the level of compliance associated with child characteristics (sex, birth weight, nutritional status, morbidity, hemoglobin concentration) or feeding mode (breastfed)? and, 4) Is the level of compliance associated with household factors (parental marital status, education, employment, as indigenous origin, religion, socioeconomic status)?

\section{Materials and methods}

\section{Study design}

Data from a randomized, double-blind, controlled trial carried out in a semi-rural community of Morelos, Mexico from April 1'st 1998 to September 31, 2003, was used for this study. ${ }^{18}$ The main objective of the original study was to determine if a daily intake of multiple micronutrient syrup improved growth and development in early childhood compared with a syrup that contained only iron and vitamin A supplement in children from 3 to 24 months of age. The experimental group received approximately a daily recommended intake (RDA) of vitamins $\mathrm{A}, \mathrm{C}, \mathrm{D}, \mathrm{E}$, niacin, riboflavin, $\mathrm{B}_{1}, \mathrm{~B}_{6}, \mathrm{~B}_{12}$ and folic acid, as well as iron, magnesium and zinc (table I).${ }^{19}$ The control group received a supplement with the same type and quantities of iron and vitamin A. Both supplements were distributed six days a week, by trained field staff

Table I

Table I
COMPOSITION OF THE MULTIPLE MICRONUTRIENT
SUPPLEMENT FOR CHILDREN ACCORDING TO AGE GROUP.
MORELOS, MEXICO, I 998-2003

Nutrient

\begin{tabular}{cc}
\multicolumn{2}{c}{ Age group } \\
\hline 3-II months & $12-24$ months \\
(per dose, $20 \mathrm{~mL})$ & (per dose, $30 \mathrm{~mL}$ )
\end{tabular}

\begin{tabular}{lcc} 
Vitamin $\mathrm{A}, \mathrm{UI}$ & 450 & 480 \\
\hline Vitamin $\mathrm{C}, \mathrm{mg}$ & 52.5 & 60.0 \\
\hline Vitamin $\mathrm{D}, \mathrm{UI}$ & 400 & 400 \\
\hline Vitamin $\mathrm{E}, \mathrm{UI}$ & 4.0 & 6.0 \\
\hline Niacin, $\mathrm{mg}$ & 6.0 & 9.0 \\
\hline Vitamin $\mathrm{B}_{1}, \mathrm{mg}$ & 0.40 & 0.70 \\
\hline Vitamin $\mathrm{B}_{2}, \mathrm{mg}$ & 0.75 & 1.20 \\
\hline $\begin{array}{l}\text { Vitamin } \mathrm{B}_{6}, \mathrm{mg} \\
\text { Vitamin } \mathrm{B}_{12}, \mu \mathrm{g}\end{array}$ & 0.60 & 1.00 \\
\hline $\begin{array}{l}\text { Folic acid, } \mu \mathrm{g} \\
\text { Iron, } \mathrm{mg}\end{array}$ & 0.75 & 1.05 \\
\hline $\begin{array}{l}\text { Magnesium, mg } \\
\text { Zinc, } \mathrm{mg}\end{array}$ & 35.0 & 50.0 \\
\hline * The control group received the same type and quantities of iron and \\
vitamin $\mathrm{I}$
\end{tabular}


and their intake was supervised and registered daily. The supplement pre-mixture was made and donated by Vitamin Roche Laboratories (Mexico City), and both the intervention and control syrups were prepared weekly in a dedicated laboratory at the National Institute of Public Health (INSP), Cuernavaca, Mexico. The syrup recipe was formulated by the Physiology of Nutrition Laboratory of the National Institute of Medical Sciences and Nutrition Salvador Zubirán, Mexico City, who also trained chemists in its preparation.

\section{Study subjects and recruitment}

The study was carried out in a semi-rural community of Morelos state, Mexico with a total population of approximately 19500 inhabitants. The study children were the offspring of women who had participated in original double blind randomized trial..$^{20,21}$ The children were followed up to 3 months of age as part of the prenatal study, at which point they were recruited to participate in the child supplementation study. Children with congenital anomalies or consuming other types of supplement were excluded. The objectives, procedures, risks and benefits of the study were explained to mothers (or principal caregivers), and if willing to participate were asked to sign an informed consent declaration. The research protocol was approved by the Ethics, Research and Biosecurity Commissions of INSP in Cuernavaca, Mexico and by the Institutional Review Board of Emory University in Atlanta.

\section{Data collection and processing}

As part of the prenatal study, child's weight, length and birth date were registered at delivery. When children were recruited (3 months of age), anthropometric measurements were taken and information collected on feeding practices, housing conditions, possession of household goods, marital status, religion and mothers spoke or understood Nahuatl language, as well as education level (schooling) and parents employment.

Supplement intake was registered by field staff through daily home visits from Monday to Saturday, including the remaining quantity in $\mathrm{mL}$ as well as if the consumed amount was spat or vomited, classifying it as nothing, something or everything. In these daily visits information about presence of diarrhea, cough, flu and fever on the previous day, was obtained. A capillary blood sample was obtained to determine hemoglobin concentration with a portable photometer, which has been validated in Mexican population. ${ }^{22}$ Height for age, length for age and weight for length Z-scores were constructed utilizing the child growth standards. ${ }^{23}$
At recruitment, children were classified as exclusively breastfed (breast milk only), predominantly breastfed (breast milk plus water or water based drinks), partially breastfed (breast milk plus other fluids including any type of milk) or breastfed with solid foods. The family socioeconomic status index was constructed with housing characteristics and possession of household goods, utilizing the first principal component obtained from principal components, as in previous analysis performed in Mexican population..$^{1,2}$ This index was then categorized in tertiles with the higher tertile representing better socioeconomic characteristics.

The real compliance of multiple micronutrient supplement or iron and vitamin A was calculated by dividing the number of days the child consumed the supplement, by the number of days the field staff visited to administer the syrup, and then multiplied by 100 . Since there were days when field staff did not make home visits to administer the supplement (e.g. on holidays), we also calculated ideal compliance by dividing the number of days that the child took the supplement, by the total of days corresponding to the 21 months of treatment (546), multiplied by 100 . Adequate compliance was defined as the real compliance rate equal or higher than $80 \%$, based on the mean value, which is also consistent with other published articles. 5,10,13-15,24

Rates of diarrhea, coughing, cold and fever were calculated by dividing the number of days the child had the symptom in the interval between 3 to 24 months old, by the number of days for which data were available and multiplied by 100 . Anemia was diagnosed as hemoglobin concentration $<110 \mathrm{~g} / \mathrm{L} .{ }^{25}$

\section{Statistical analysis}

The success of randomization was assessed by comparing baseline characteristics by supplement group. Characteristics of children who completed the trial were also compared with those who dropped out. Student's $t$-test were used for comparison of continuous variables with a normal distribution, or a Mann-Whitney test. For categorical data, Chi-square or Fisher's exact test were used, the latter when the expected value was five or less in any cell.

The association between supplement group and adequate compliance was assessed using logistic regression adjusting for factors that were different between groups at baseline and predictors of compliance as socioeconomic and child characteristics, type of breastfeeding and morbidity, based on a priori consideration that in addition to supplement characteristics, child (age, sex, baseline anemia, birthweight) and household factors (indigenous origin, maternal education and nutritional 
status, economic well-being of the household) may affect compliance with supplementation. The potential modifying effects of baseline hemoglobin concentration, indigenous origin, maternal education, height for age at baseline on compliance by group were tested as a statistical interaction between them. The model was assessed by goodness of fit test of Hosmer and Lemeshow. ${ }^{26}$ The statistical significance was considered for a $p<0.05$ for the main effects and $p<0.10$ for the interactions. The statistical analysis was performed using STATA 8.0.

\section{Results}

Of the 654 children recruited, 465 (71.1\%) finished the study and 189 (28.9\%) dropped out before 24 mo of age (figure 1). Reasons for dropping out of the study have been published elsewhere ${ }^{18}$ and the most important were parents or tutors withdrawing their permission to participate (61.9\%), moving out to another community $(12.7 \%)$, disliking the supplement or ill feeling after consuming it $(12.2 \%)$. When comparing children who completed the study with those who dropped out, a statistically significant difference was observed $(p<0.05)$ for maternal age $(23.8 \pm 5.5$ vs. $22.2 \pm 4.1$ years $)$, maternal education ( $6.6 \pm 3.3$ vs. $7.4 \pm 3.4$ years), and coughing (17.3 vs. $26.7 \%)$. For the remaining variables, including the type of supplement, statistically significant differences were not found (table II).
Of the group of children that completed the study, $55.3 \%$ were male, $7.8 \%$ weighed less than $2500 \mathrm{~g}$ at birth, $2.9 \%$ had low length-for-age at three months old, $43.7 \%$ suffered anemia and $16.3 \%$ were exclusively breastfed at three months. On average, maternal age was $23.8 \pm$ 5.5 years, $31.5 \%$ spoke or understood Nahuatl language, $4.5 \%$ were single or had no couple and $6.9 \%$ had a paid employment. Fathers had a better education level than mothers with $7.8 \pm 3.4$ and $6.6 \pm 3.3$ years of study, respectively.

The analysis of compliance was performed with data from children who completed the study, 237 (51\%) belonged to the multiple micronutrient group and 228 (49\%) to the iron and vitamin A group. At baseline, a statistically significant difference between groups were found for maternal age $(23.4 \pm 5.8$ vs. $24.2 \pm 5.2$ years, $p=0.030$ ), and for the percentage of mothers with a paid job (4.7 vs. 9.3\%, $p=0.048$ ) (table III). There were no differences between groups for the socioeconomic index, anthropometric characteristics, feeding practices or child morbidity.

The mean number of days that the children consumed the iron and vitamin A supplement was significantly $(p=0.025)$ higher $(429.1 \pm 53.0)$ than the multiple micronutrient group $(417.5 \pm 57.1)$. The real compliance rate was also significantly higher $(p=0.044)$ in the iron and vitamin A group (81.8\%, inter-quartile range (IQR) 75.2-87.5) than the multiple micronutrient group $(79.5 \%$,

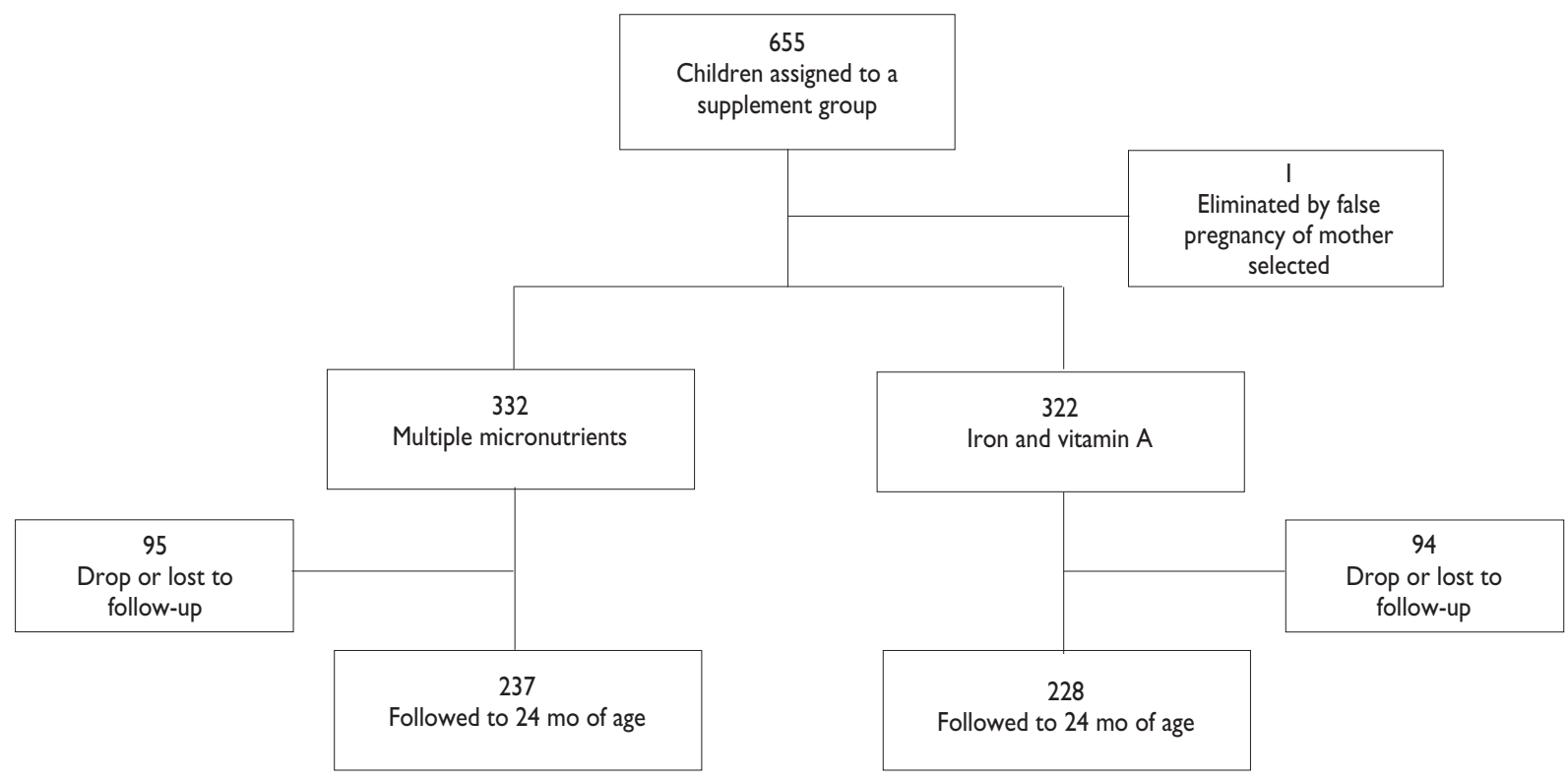

Figure I. Flow diagram of the study design and sample size for the studied population. Morelos, Mexico, 1998-2003 
Table II

Comparison OF GeNERAL CHARACTERISTICS BETWEeN THE SAMPLE OF CHILDREN WHO COMPLETED THE STUDY AND THE FOLLOW UP DROP OUTS. Morelos, Mexico 1998-2003

Characteristics

$\begin{array}{cc}\text { Children that } & \text { Follow up } \\ \text { completed the study } & \text { drop outs } \\ (n=465) & (n=189)\end{array}$

Multiple micronutrients (\%)

51.0

50.3

Children

\begin{tabular}{|c|c|c|}
\hline Age (months) & $3.0 \pm 0.1$ & $3.0 \pm 0.1$ \\
\hline Male (\%) & 55.3 & 54.5 \\
\hline Birth weight $(\mathrm{kg})$ & $3.1 \pm 0.4$ & $3.0 \pm 0.4$ \\
\hline Z score for length-age & $-0.5 \pm 1.0$ & $-0.5 \pm 1.1$ \\
\hline Z score for weight-age & $-0.3 \pm 1.0$ & $-0.5 \pm 1.1$ \\
\hline Z score for weight-length & $0.1 \pm 0.9$ & $0.0 \pm 1.0$ \\
\hline Diarrhea (\%) & 2.1 & 5.6 \\
\hline Cough (\%) & 17.3 & $26.7^{*}$ \\
\hline Cold (\%) & 15.6 & 20.3 \\
\hline Fever $(\%)$ & 2.1 & 4.0 \\
\hline Hemoglobin $(g / L)$ & $111.5 \pm 10.7$ & $110.5 \pm 11.0$ \\
\hline Anemia (hemoglobin <110 g/L) (\%) & 43.7 & 45.9 \\
\hline Exclusive breastfeeding at $3 \mathrm{mo}(\%)$ & 16.3 & 12.3 \\
\hline
\end{tabular}

Mother

\begin{tabular}{lcc} 
Age (years) & $23.8 \pm 5.5$ & $22.2 \pm 4.1^{*}$ \\
\hline Single mother (\%) & 4.5 & 3.8 \\
\hline Speaks Nahuatl (\%) & 31.5 & 23.9 \\
\hline Catholic religion (\%) & 88.1 & 90.2 \\
\hline Illiteracy (\%) & 6.7 & 4.9 \\
\hline Schooling (years) & $6.6 \pm 3.3$ & $7.4 \pm 3.4^{*}$ \\
\hline Paid job (\%) & 6.9 & 5.5
\end{tabular}

Father

\begin{tabular}{lcc} 
Illiteracy (\%) & 4.5 & 2.2 \\
\hline Schooling (years) & $7.8 \pm 3.4$ & $7.9 \pm 3.4$ \\
\hline Socioeconomic index & $-0.10 \pm 0.98$ & $0.06 \pm 0.96$ \\
$* p<0.05$ from Mann-Whitney test & &
\end{tabular}

IQR: 72.8-86.1). Similarly, the percentage of children with an adequate compliance rate (consumed on at least 80\% of days offered) in the iron and vitamin A group (60.1\%) was significantly $(p=0.016)$ higher than the multiple micronutrient group (48.9\%). The real compliance was significantly higher $(p=0.025)$ in the iron and vitamin A group (80.3, IQR:73.6-86.0) than the multiple micronutrient group (78.2, IQR: 71.1-84.1).

The odds of adequate compliance (>than $80 \%$ ) were $59 \%$ greater in the children supplemented with iron and
Table III

General Characteristics at baseline of the CHILDRen INCLUDED IN THE ANALYSIS BY SUPPLEMENTATION GROUP.* Morelos, Mexico 1998-2003

\begin{tabular}{|c|c|c|c|c|}
\hline \multirow[t]{2}{*}{ Characteristics } & \multicolumn{4}{|c|}{ Group } \\
\hline & N & $\begin{array}{c}\text { Multiple } \\
\text { micronutrients }\end{array}$ & N & $\begin{array}{l}\text { Iron and } \\
\text { vitamin } A\end{array}$ \\
\hline \multicolumn{5}{|l|}{ Children } \\
\hline Age (months) & 228 & $3.0 \pm 0.1$ & 226 & $3.0 \pm 0.1$ \\
\hline Male (\%) & 130 & 54.8 & 127 & 55.7 \\
\hline Birth weight $(\mathrm{kg})$ & 236 & $3.1 \pm 0.4$ & 226 & $3.1 \pm 0.4$ \\
\hline Z score for length-age & 225 & $-0.4 \pm 0.9$ & 225 & $-0.5 \pm 0.9$ \\
\hline Z score for weight-age & 212 & $-0.3 \pm 1.0$ & 216 & $-0.3 \pm 1.0$ \\
\hline Z score for weight-length & 214 & $0.1 \pm 0.9$ & 217 & $0.2 \pm 1.0$ \\
\hline Low length $\ddagger$ (\%) & 225 & 6.6 & 225 & 6.2 \\
\hline Low weight ${ }^{\S}(\%)$ & 214 & 1.2 & 217 & 1.0 \\
\hline Diarrhea (\%) & 237 & $2.2 \pm 2.5$ & 228 & $2.0 \pm 2.0$ \\
\hline Cough (\%) & 237 & $17.4 \pm \mid 1.3$ & 228 & $17.2 \pm 1 \mid .4$ \\
\hline Cold (\%) & 237 & $15.3 \pm 9.6$ & 228 & $16.0 \pm 10.6$ \\
\hline Fever (\%) & 237 & $2.2 \pm 1.6$ & 228 & $2.0 \pm 1.5$ \\
\hline Hemoglobin $(g / L)$ & 186 & $111.5 \pm 10.7$ & 178 & $111.6 \pm 10.8$ \\
\hline Anemia ${ }^{\#}(\%)$ & 186 & 41.9 & 178 & 45.5 \\
\hline \multicolumn{5}{|l|}{ Breastfeeding (\%) } \\
\hline No breastfeeding & 4 & 2.0 & 4 & 1.9 \\
\hline Exclusive & 37 & 18.2 & 30 & 14.4 \\
\hline Predominantly\& & 108 & 53.2 & 124 & 59.6 \\
\hline Formula $^{\neq}$ & 38 & 18.7 & 35 & 16.8 \\
\hline Food $^{\infty}$ & 16 & 7.9 & 15 & 7.2 \\
\hline
\end{tabular}

Mother

\begin{tabular}{lcccc} 
Age (years) & 237 & $23.4 \pm 5.8$ & 228 & $24.3 \pm 5.2^{\circ}$ \\
\hline Single mother (\%) & 237 & 4.6 & 227 & 4.4 \\
\hline Speaks Nahuatl (\%) & 237 & 29.5 & 227 & 33.5 \\
\hline Catholic religion (\%) & 236 & 88.1 & 227 & 88.1 \\
\hline Illiteracy (\%) & 235 & 8.1 & 226 & 5.3 \\
\hline Schooling (years) & 237 & $6.7 \pm 3.3$ & 226 & $6.5 \pm 3.2$ \\
\hline Paid job (\%) & 236 & 4.7 & 225 & 9.3
\end{tabular}

Father

\begin{tabular}{lcccc} 
Illiteracy (\%) & 237 & 5.1 & 226 & 4.0 \\
\hline Schooling (years) & 234 & $7.7 \pm 3.5$ & 219 & $8.0 \pm 3.4$ \\
\hline Socioeconomic Index & 233 & $-0.18 \pm 0.98$ & 221 & $-0.01 \pm 0.96 €$
\end{tabular}

* Anthropometry, hemoglobin, breastfeeding and socioeconomic index data were obtained when children were 3 months of age ( \pm 2 weeks)

$\ddagger<-2 S D$ of length-age

$\S<-2 S D$ weight-length

\# Hemoglobin < $110 \mathrm{~g} / \mathrm{L}$

\& Breastfeeding and liquids

* Breastfeeding and other type of milk

${ }^{\infty}$ Breastfeeding and solid food

${ }^{\circ} p=0.030$, from Chi square test

$p=0.048$, from Chi square test

$€ p=0.05$ I, from Chi square test 
vitamin A than with multiples micronutrients, although the estimate was only marginally significant $(p=0.052)$ (table IV). Overall, the probability of adequate compliance (i.e. compliance higher than $80 \%$ ) was 0.51 for the multiple micronutrient group and 0.59 for the vitamin A and iron group ( $p=0.051)$.

The odds of adequate compliance to supplementation were 2.09 ( $95 \%$ CI: 1.28, 3.40) times higher for every increment of 100 grams of weight at birth $(p=0.003)$ (table IV). Children of families of indigenous origin (spoke or understood Nahuatl language) had 1.56 (95\% CI: 0.96, 2.54) the odds of adequate compliance with supplementation than children of non-indigenous mothers $(p=0.071)$. Furthermore, for every additional completed year of formal education, the odds of adequate supplement were reduced by $13 \%(p<0.001)$. Finally, higher rates of morbidity resulted in lower odds of adequate compliance. For each point increase in the percentage of dates with cough or fever, resulted in a decrease of 5 and $15 \%$ in the odds of adequate compliance $(p<0.001$ and $p=0.024$ ), respectively. None of the interaction terms tested were statistically significant $(p>0.10)$.

\section{Discussion}

Overall compliance to supplementation with micronutrient syrup was very high in both the intervention and control groups. This was not surprising given the

Table IV

LOGISTIC REGRESSION FOR ADEQUATE COMPLIANCE.* Morelos, Mexico I 998-2003

\begin{tabular}{|c|c|c|c|}
\hline Variable & Odds Ratio & $95 \%, \mathrm{Cl}$ & $P$ \\
\hline Multiple micronutrients & 0.63 & $0.44-1.00$ & 0.052 \\
\hline Maternal age (years) & 1.01 & $0.97-1.06$ & 0.520 \\
\hline Mothers with paid employment & 0.84 & $0.38-1.90$ & 0.683 \\
\hline Socioeconomic index $\ddagger$ & 1.08 & $0.87-1.35$ & 0.482 \\
\hline Birth weight $(100 \mathrm{~g})$ & 2.09 & $1.28-3.40$ & 0.003 \\
\hline Indigenous origin ${ }^{\S}$ & 1.56 & $0.96-2.54$ & 0.071 \\
\hline Maternal schooling (years) & 0.87 & $0.82-0.94$ & $<0.001$ \\
\hline Cough (\%) & 0.95 & $0.93-0.97$ & $<0.001$ \\
\hline Fever (\%) & 0.85 & $0.73-0.98$ & 0.024 \\
\hline
\end{tabular}

* Adequate compliance was defined as the real compliance rate equal or higher than $80 \%$; $(n=447$, due to missing values for some of the covariates); test of Hosmer and Lemeshow ${ }^{26} p=0.628$

\# Socioeconomic index was constructed with housing characteristics and possession of household goods, utilizing the first principal component obtained in the analysis of principal components

$\S$ Indigenous origin was defined as mothers spoke or understood Nahuatl language controlled conditions. Similar or higher average intakes in controlled trials have been reported (80 to $96 \%$ ). 5,27-29 An important finding of this study was that compliance differed by supplement type, although the estimate was only marginally significant. As this was a double blinded randomized trial, this implies that supplement characteristics can influence the individual willingness to consume it, even under controlled conditions.

Although it has been shown that supplement presentation influences compliance, there is little evidence that nutrient content affects acceptance and intake of nutritional supplements. Contrary to our findings, in a controlled supplementation trial performed with Mexican children from 8 to 14 months old a better compliance rate was found in the multiple micronutrient group than in the placebo group (91 vs. $80.5 \%, p<0.05) .{ }^{5}$ In other studies, using different supplement types, no significant difference has been found between groups with different nutritional content. For example, in school-aged children in Tanzania, compliance of the group that consumed a multiple micronutrient fortified beverage $(79.9 \%)$ was similar to the control group (81.1\%). ${ }^{27}$ In the Philippines, compliance in a group of schoolchildren receiving a multiple-micronutrient-fortified beverage was of $95.9 \%$, while in the placebo group was of $96.3 \% .{ }^{29}$ In a controlled trial conducted in 6 to 18 months old children from a rural area of Ghana, a microencapsulated ferrous fumarate plus ascorbic acid supplement consumed with complementary foods (trade mark Sprinkles) had a lower compliance rate than ferrous sulfate drops (66 vs. $81 \%$ ). Although it was not mentioned whether this difference was statistically significant, the authors argued that in this case this difference could be due to age of introduction and frequency of complementary food intake and humidification of the micronutrient powder due to problems with packaging. ${ }^{13}$

One of the difficulties to compare compliance rates across studies is the difference in methods used to measure it. It is possible that the compliance figures are influenced by the way information is collected. These measurements include the daily supervised record by trained personnel for this purpose, $, 14,15,27$ weekly interviewed record, ${ }^{6}$ pill bottle equipped with an electronic counting device ${ }^{30,31}$ and biochemical determinations. ${ }^{7}$ In our study, we have high confidence in our compliance figures given that supplementation was daily and observed by project staff. This may explain a lower compliance rate in relation to other studies in which there may be memory or reporting bias. In addition, it has been observed in controlled trials in children that multiple micronutrient supplementation periods vary from 2 to 12 months. ${ }^{4,5,27,28}$ The duration of supplementation may influence compliance through fatigue. 
In our study, the rate of adequate compliance (greater than 80\%) was significantly different $(p<0.05)$ between the multiple micronutrient and iron (48.9\%) and vitamin A group (60.1\%). A possible explanation of this difference may be the side effects caused by some micronutrients contained in the supplement. It is known that iron intake could cause diarrhea, constipation, nausea, vomiting, dizziness, epigastric pain and dark feces when administered at physiological doses. ${ }^{9,11,32}$ Although in young children it may be difficult to document these symptoms, mothers have reported that when iron is administered as drops, $74 \%$ have rejected the supplement (cry, make gestures, or spit drops) while when administered as powder mixed with food, this percentage has been $16 \% .{ }^{13}$ However, given that the iron content and form of the two supplements was the same, it seems unlikely that the differences in compliance are related to iron-related side effects.

Other nutrients contained in the multiple micronutrient supplement have been associated with transient side effects. Niacin administered in high doses (1 to 2 $\mathrm{g}$ three times per day) as nicotinic acid can result in flushing and sensation of heat especially in the face, neck and ears. ${ }^{32,33}$ This reaction is usually mild, however, when it becomes unbearable my cause dropout rates of more than $50 \% .{ }^{32}$ Side effects such as diarrhea, nausea, vomiting, abdominal pain, dermatitis, allergic reactions, anorexia, headaches, and drowsiness, among others have also been documented for magnesium and vitamin C, B1, B6, B12 and folic acid, while zinc, and vitamin A, D, E and B2 are reported to be well tolerated in recommended doses. ${ }^{32}$ Although similar in appearance, it is possible that the multiple micronutrient syrup had characteristics less acceptable to the children and/ or mothers that resulted in greater refusal to offer or consume it. To ensure that supplement properties do not affect acceptability it is vital to ensure minimum quality control criteria including stability, homogeneity, viscosity, solubility and sterility.

We found a positive association between birth weight and compliance with supplementation, i.e., children born with higher weight were more likely to have better compliance. Hence, infants born with low birth weight which are at higher risk of morbidity and mortality are missing the opportunity to be most benefitted from nutritional supplementation. ${ }^{34}$ It is therefore very important to understand why children with lower birth weight complied less and how these barriers could be overcome. Our results indicate that the association between birth weight with compliance is independent of concurrent health status, since the model was adjusted for morbidity (diarrhea, cough and fever percentage). It is possible that association of adequate compliance with adequate birth weight is due to the differentiated reaction that mothers have about weight perception of their children. In relation to this, people's beliefs about health and supplement treatments may interfere with compliance. For example, some pregnant women from Thailand decided not to take iron supplements out of fear of having a larger baby and a difficult delivery. ${ }^{10}$

In this study we found less adequate compliance when the percentage of time with cough and fever was higher. This could be due to infections reducing dietary intake by decreasing appetite. ${ }^{35,36}$ In Mexico, some mothers of children with diarrhea decide to suspend the use of multiple micronutrient supplementation in the form of gruel while others keep administering it, in which case the diarrhea disappears within a few days. ${ }^{37}$ In developing countries, other factors associated with compliance to medical treatment include illiteracy, low education and belonging to an ethnic group. ${ }^{16} \mathrm{It}$ is known that indigenous communities may have lower acceptance of nutritional supplements. ${ }^{38}$ In contrast, in this study we found marginally higher compliance among those of indigenous origin. We also found that compliance was higher among more vulnerable groups, e.g., children whose mothers had less formal education. This may be related to the fact that the supplementers in this study were from the community and could better address concerns and hesitation among residence with different characteristics. Future studies should include qualitative methods for a better understanding of the factors that help motivate women to comply with supplementation, how to overcome barriers to supplementation and take advantage of opportunities for adequate compliance.

There is evidence of a consistent and positive association between motivation and therapeutic treatment compliance, related to the health provider ability to advise and to make an empathic and affective approach with the patient. ${ }^{39,40}$ In a vitamin A supplementation cohort trial, performed in Indonesia in children under 5 years old, there was an association between compliance of the caregivers and their knowledge about the potential benefits of this vitamin supplementation. ${ }^{41}$ Pregnant women who received iron supplements, forgot to take the pills because of a lack of motivation and understanding about anemia. ${ }^{7}$ It has been documented that the role and the attitude of the mother towards the supplement is vital for the child to consume it. In supplementation programs mothers get "tired" of giving iron daily doses after three month and because of the daily intake some children get fed up of the supplement flavour for which the mothers give them a "rest". ${ }^{37,41}$ Perceived health benefits may help overcome this barrier. 
In conclusion, the compliance rate found in this study is consistent with the assessments made in randomized trials, and as expected, higher than in supplementation programs for children. However, the compliance rate was different between the supplement groups, even though the estimate was only marginally significant, possibly due the characteristics of the supplements themselves or side effects of the micronutrient supplement. If these effects cause more diarrhea or gastrointestinal problems when adjusting for these variables, the difference between groups should have disappeared. This was not the case and we conclude that side effects were not the principal determinant of lower compliance. An understanding of factors that influence compliance is vital to ensure that barriers and opportunities for adequate compliance can be taken into consideration in communication strategies.

Declaration of conflict of interests: The authors declares not to have conflict of interests.

\section{References}

I. Villalpando S, Shamah-Levy T, García-Guerra A, Mundo-Rosas V, Domínguez C, Mejía-Rodríguez F. The prevalence of anemia decreased in Mexican preschooland school-age children from 1999 to 2006. Salud Publica Mex 2009;5 I suppl 4:S507-S5I4.

2. Rivera-Dommarco J, Shamah-Levy T, Villalpando-Hernández S, González de Cossío T, Hernández-Prado B, Sepúlveda J. Encuesta Nacional de Nutrición 1999. Estado nutricio de niños y mujeres en México. Cuernavaca, Morelos, México: Instituto Nacional de Salud Pública, 2001. 3. Barquera S, Rivera-Dommarco J, Gasca-García A. Políticas y programas de alimentación y nutrición en México. Salud Publica Mex 200I; 43:464-477.

4. Rivera JA, Hotz C, González-Cossío T, Neufeld L, García-Guerra A. The effect of micronutrient deficiencies of child growth: a review of results from community-based supplementation trials. J Nutr 2003; 133: 40IOS-4020S.

5. Rivera JA, González-Cossío T, Flores M, Romero M, Rivera M, TéllezRojo M, et al. Multiple micronutrient supplementation increases the growth of Mexican infants. Am J Clin Nutr 200I; 74: 657-663.

6. Rivera JA, Sotres-Alvarez D, Habicht JP, Shamah T, Villalpando S. Impact of the Mexican program for education, health, and nutrition (PROGRESA) on rates of growth and anemia in infants and young children. JAMA 2004; 29I: 2563-2570.

7. Schultink W, Ree M, Matulessi P, Gross R. Low compliance with an iron-supplementation program: a study among pregnant women in Jakarta, Indonesia. Am J Clin Nutr 1993; 57: 135-39.

8. Allen LH. Nutritional supplementation for the pregnant woman. Clin Obstet Gynecol 1994; 37: 587-595.

9. Charoenlarp P, Dhanamitta S, Kaewvichit R, Silprasert A, Suwanaradd C, Na-Nakorn S, et al. A WHO collaborative study on iron supplementation in Burma and in Thailand. Am J Clin Nutr 1988; 47: 280-297.

10. Galloway R, McGuire J. Determinants of compliance with iron supplementation: supplies, side effects, or psychology? Soc Sci Med 1994; 39: $381-390$.
II. Allen LH. Iron supplements: scientific issues concerning efficacy and implications for research and programs. J Nutr 2002; I32 suppl 4: 8|3-819. 12. Cromer BA, Steinberg K, Gardner L, Thornton D, Shannon B. Psychosocial determinants of compliance in adolescents with iron deficiency. Am J Dis Child 1989; 143: 55-58.

13. Zlotkin S, Arthur P, Antwi KY, Yeung G. Treatment of anemia with microencapsulated ferrous fumarate plus ascorbic acid supplied as sprinkles to complementary (weaning) foods. Am J Clin Nutr 200I; 74: 79I-795. 14. Rosado JL, Rivera J, López G, Solano L, Rodríguez G, Casanueva E, et al. Desarrollo y evaluación de suplementos alimenticios para el Programa de Educación, Salud y Alimentación. Salud Publica Mex 1999;4I: I53-I62. 15. Rivera JA, Rodríguez G, Shamah T, Rosado JL, Casanueva E, Maulén I, et al. Implementation, monitoring, and evaluation of the nutrition component of the Mexican Social Program (PROGRESA). Food Nutr Bull 2000; 21: 35-42.

16. Homedes N, Ugalde A. Research on patient compliance in developing countries. Bull Pan Am Health Organ 1994; 28: 17-33.

17. Murmu LR, Murmu D, Kant S. Supplementation study compliance and the role of health care staff. Am J Clin Nutr 1994; 59: 433-434.

I8. Ramakrishnan U, Neufeld LM, Flores R, Rivera J, Martorell R. Multiple micronutrient supplementation during early childhood increases child size at 2 y of age only among high compliers. Am J Clin Nutr 2009;89: | |25-||3|.

19. National Research Council. Recommended Dietary Allowances. $10^{\text {th }}$ edition. Washington, D.C: National Academy Press, 1989.

20. Ramakrishnan U, Gonzalez-Cossio T, Neufeld LM, Rivera J, Martorell R. Multiple micronutrient supplementation during pregnancy does not lead to greater infant birth size than does iron-only supplementation: a randomized controlled trial in a semi rural community in Mexico. Am J Clin Nutr 2003; 77: 720-725.

21. Ramakrishnan U, Neufeld L, Gonzalez-Cossio T, Villalpando S, GarciaGuerra A, Rivera J, et al. Multiple micronutrient supplements during pregnancy do not reduce anemia or improve iron status compared to iron-only supplements in semi-rural Mexico. J Nutr 2004; I34: 898-903. 22. Neufeld L, García-Guerra A, Sánchez-Francia D, Newton Sánchez $O$, Ramírez Villalobos MD, Rivera Dommarco J. Haemoglobin measured by Hemocue and a reference method in venous and capillary blood: a validation study. Salud Publica Mex 2002; 44: 219-227.

23. World Health Organization. WHO Child Growth Standards. Length/ height-for-age, weight-for-age, weight-for-length, weight-for-height and body-mass-index-for-age. Methods and development. Geneva: WHO, 2006.

24. Hyder SM, Persson LA, Chowdhury AM, Ekström EC. Do side-effects reduce compliance to iron supplementation? A study of daily- and weekly- dose regimens in pregnancy. J Health Popul Nutr 2002; 20: I75-179. 25. World Health Organization. The prevalence of anemia in women: a tabulation of available information. $2^{\text {nd }}$ ed. Ginebra: WHO, 1992. 26. Hosmer DW, Lemeshow S. Applied Logistic Regression. $2^{\text {nd }}$ ed. NJ, USA: John Wiley \& Sons, 2000.

27. Latham MC, Ash DM, Makola D, Tatala SR, Ndossi GD, Mehansho H. Efficacy trials of micronutrient dietary supplement in schoolchildren and pregnant women in Tanzania. Food Nutr Bull 2003; 24: SI20-SI 28. 28. Smuts CM, Dhansay MA, Faber M, van Stuijvenberg ME, Swanevelder $\mathrm{S}$, Gross R, et al. Efficacy of multiple micronutrient supplementation for improving anemia, micronutrient status, and growth in South African infants. J Nutr 2005; 135: 653S-659S.

29. Solon F, Sarol JN Jr, Bernardo AB, Solon JA, Mehansho H, Sanchez L, et al. Effect of multiple-micronutrient-fortified fruit powder beverage on the nutrition status, physical fitness, and cognitive performance of schoolchildren in the Philippines. Food Nutr Bull 2003; 24: SI29-SI 40.

30. Ekstrom EC, Hyder SM, Chowdhury AM, Chowdhury SA, Lonnerdal $B$, Habicht JP, et al. Efficacy and trial effectiveness of weekly and daily iron supplementation among pregnant women in rural Bangladesh: disentangling the issues. Am J Clin Nutr 2002; 76: I392-1400. 
31. Hyder SM, Persson LA, Chowdhury AM, Ekstrom EC. Do side-effects reduce compliance to iron supplementation? A study of daily- and weekly -dose regimens in pregnancy. J Health Popul Nutr 2002; 20: I75-179. 32. Mayo Foundation for Medical Education and Research. Vitamin and mineral supplements: use with care. Medline Plus Web site. [Accessed: 2005 june 30]. Available at: http://www.nlm.nih.gov/medlineplus/vitaminsandminerals.html.

33. Combs-Gerald F. Jr. Vitaminas. En: Mahan L. Kathleen, Escott-Stump Sylvia, Ed. Nutrición y dietoterapia de Krause, $10^{a}$ edición. México, DF: McGraw-Hill, 200I: 73-II9.

34. Organización Mundial de la Salud. El estado físico: uso e interpretación de la antropometría. Serie de Informes Técnicos N 854. Ginebra: OMS, 1995.

35. Fondo de la Naciones Unidas para la Infancia. Estado mundial de la infancia. Tema: nutrición. Nueva York: UNICEF, 1998.

36. Scrimshaw NS, Suskind RM. Interactions of nutrition and infection. Dent Clin North Am 1976;20:46I-472.
37. Zarco A, Mora G, Pelcastre B, Flores M, Bronfman M. Aceptabilidad de los suplementos alimenticios del programa Oportunidades. Salud Publica Mex 2006;48:325-331.

38. Mora JO. Iron supplementation: overcoming technical and practical barriers. J Nutr 2002; 132 (4 suppl): 853S-855S.

39. Squier RW. A model of empathic understanding and adherence to treatment regimens in practitioner-patient relationships. Soc Sci Med 1990; 30: 325-339.

40. Pangaribuan R, Erhardt JG, Scherbaum V, Biesalski HK. Vitamin A capsule distribution to control vitamin A deficiency in Indonesia: effect of supplementation in pre-school children and compliance with the programmed. Public Health Nutr 2003; 6: 209-2I6.

4I. Nestel P, Alnwick D. Iron/ multimicronutrient supplements for young children. Copenhague: USAID/ UNICEF, 1996. 